\title{
Anthropometric Profile and Functional Performance of Capoeira Competitors in the World Games
}

\author{
Perfil Antropométrico y Desempeño Funcional de los \\ Competidores de Capoeira en los Juegos Mundiales
}

\author{
Lucas Guimarães Almeida ${ }^{1}$; Eduardo Seiji Numata Filho' ${ }^{1}$; Geovani Alves dos Santos ${ }^{1}$; \\ José Tadeu Carneiro Cardoso ${ }^{2} \&$ Sergio Rodrigues Moreira ${ }^{1}$
}

\begin{abstract}
ALMEIDA, L. G.; NUMATA FILHO, E. S.; DOS SANTOS, G. A.; CARDOSO, J. T. C. \& MOREIRA, S. R. Anthropometric profile and functional performance of capoeira competitors in the world games. Int. J. Morphol., 39(4):969-976, 2021.

SUMMARY: This study aimed to characterize the anthropometric profile and functional performance of elite competitors in different categories in the world championship of the ABADÁ-Capoeira School. Fifty high level male athletes were divided according to their weight categories, being: light category (VIOLA: $\leq 76.9 \mathrm{~kg} ; \mathrm{n}=15$ ); intermediate category (MEDIO: $>77.0 \mathrm{~kg}$ until $\leq 85.9 \mathrm{~kg} ; \mathrm{n}$ $=25$ ) and heavy category (GUNGA: $\geq 86.0 \mathrm{~kg} ; \mathrm{n}=10$ ). Two evaluation batteries were performed: 1) anthropometry and somatotype determination; 2) physical performance in tests of push-up, sit-up, sit-and-reach, quadrant jump test, squat jump (SJ), and counter movement jump (CMJ). The "endo-mesomorph" classification predominated in the three categories. There was a difference in the quadrant jump test between VIOLA and GUNGA subgroups $\left(\mathrm{F}_{[2.47]}=4.299 ; \mathrm{p}=0.019\right)$. Endomorphism had a negative correlation $(\mathrm{p}<$ $0.01)$ with the performance in the sit-up $(\mathrm{r}=-0.51)$, push-up $(\mathrm{r}=-0.39)$, SJ $(\mathrm{r}=-0.45)$, and CMJ $(\mathrm{r}=-0.49)$. Male elite competitors at the international level, regardless the weight category, have a predominance of the mesomorphic component of the somatotype. Moreover, all capoeira athletes were classified as excellent for the sit-and-reach, sit-up, and push-up, and the latter were positively correlated with mesomorphism. However, endomorphism was inversely associated with the sit-up, push-up, SJ, and CMJ. In this way, the present study assists coaches in the formulation of appropriate training programs aiming the development of an ideal physical composition, which will be associated with high-level performance in capoeira.
\end{abstract}

KEY WORDS: Body Composition; Physical functional performance; Athletic performance; Martial arts.

\section{INTRODUCTION}

Capoeira is considered a martial art and it is one of the most important popular manifestation in Brazil (Santos, 2001). Capoeira is defined as an athletic performance comprised of jumps, landings, spins, and attack and defense movements, which mainly requires body agility, dynamic postural balance, flexibility, motor coordination, and muscle power and endurance (Santos; Moreira et al., 2016, 2018). Moreover, capoeira is the one sport manifestation recognized by the UNESCO (United Nations Educational, Scientific and Cultural Organization) as intangible humanity heritage, and it is currently practiced in more than 150 countries across the five continents and by different social groups (Vieira \& Assunção, 2008). This martial art has been influenced by several historical periods since the $16^{\text {th }}$ century, and it englobes several aspects in its play, such as dance, fighting, acrobatics, education, artistic, and folkloric (Araújo, 1997).

Capoeira is managed by different associations, commonly denominated groups or schools. The schools have similarities in attacks and defenses movements, however, they differ regarding organizational characteristics, graduation system, and competitions (Vieira \& Assunção; Moreira, 2017). From this perspective, the ABADÁ-Capoeira School was founded in Rio de Janeiro in 1989 and it has more than 40 thousand members distributed in more than 60 countries around the world (Moreira). The ABADÁ-Capoeira School organizes biennially its world championship, which classifies the best athletes from an integrated methodology evaluating

\footnotetext{
${ }^{1}$ Graduate Program in the Department of Physical Education, Federal University of Vale do São Francisco - Univasf, PE, Petrolina, Brazil.

${ }^{2}$ Mestre Camisa; President and Founder of the "Associação Brasileira de Apoio e Desenvolvimento da Arte Capoeira - ABADÁ-Capoeira", Rio de Janeiro, Brazil.

Funding: This work was supported by the FACEPE (Research support foundation of the Brazil, Pernambuco State) under Grant IBPG-1203-4.09/16.
} 
batteries of different rhythms in the capoeira modality. Moreover, this competition divides the athletes by their technical level and body weight (BW).

The body shape and composition has become increasingly distinct among sports but similar in each of them, thus their quantification is crucial to understand the requirements and characteristics of a sport modality. Heath and Carter (Carter, 2002) proposed the somatotype technique to define the current body shape of an individual, and the somatotype quantification can be obtained anthropometrically, by photographs, or by the combination of both (Carter). Somatotype is expressed by three-number rating in the following order: 1) endomorphy; 2) mesomorphy; 3) ectomorphy, which represents relative fatness, relative muscleskeletal robustness, and relative linearity and slenderness, respectively. A value between $1 / 2$ to $2^{1 / 2}$ is considered low, 3-5 moderate, $5^{1 / 2}$ to 7 high, and above $7^{1 / 2}$ remarkably high (Carter).

The somatotype of athletes from different martial arts, such as jiu-jitsu (Andreato et al., 2012), judo (Franchini et al., 2014), taekwondo (Bridge et al., 2014), boxing (Noh et al., 2014), karate (Sánchez-Puccini et al., 2014), mixed martial arts (Marinho et al., 2016), and greco-roman wrestling (Neogi et al., 2019) is well documented in the literature, in which the mesomorphic component (MESO) predominates. Importantly, the physique of athletes has been shown to be associated with physical performance, in which performance in combat sports is positively correlated with mesomorphism, but negatively correlated with endomorphism (Pieter \& Bercades, 2009; Marinho et al., 2011). Considering that the physical abilities demanded in the modality of capoeira is similar to the ones encountered in the aforementioned combat sports, elite capoeira athletes would present predominantly the mesomorphic component. Nevertheless, studies are still necessary for the evaluation of the anthropometry and functional profile of capoeira athletes. Therefore, the present study aimed to characterize anthropometrically and functionally the profile of elite athletes, from different categories, competitors in the world championship of the ABADÁ-Capoeira School. Furthermore, this study aimed to correlate the anthropometric and functional variables. The current study hypothesized that anthropometry and somatotype would differ between BW categories. However, the overall functional performance of competitors pertaining to heavier weight categories would be similar compared to participants in lighter weight categories, since all athletes are at their highest-level performance in the modality. Such information will inform the morphofunctional characteristics in the capoeira modality, which will provide information to coaches that would contribute to a better formulation of training programs.

\section{MATERIAL AND METHOD}

Study participants. The study included males' competitors of the highest technical level (category A) in the $11^{\text {th }}$ World Championship of the ABADÁ-Capoeira School. Athletes who were not qualified to the competition were excluded. For this cross-sectional study, fifty apparently healthy athletes voluntary signed an informed consent and were assessed in August 2017 at the Mestre Bimba Educational Center in the province of Rio de Janeiro. Based on the competition rules of the ABADÁ-Capoeira School, the sample was divided into three weight categories: 1) light category (VIOLA: $\leq 76.9 \mathrm{~kg} ; \mathrm{n}=15$ ); 2) intermediate category (MEDIO: $>77.0$ until $\leq 85.9 \mathrm{~kg} ; \mathrm{n}=25$ ), and 3 ) heavy category (GUNGA: $\geq 86.0 \mathrm{~kg} ; \mathrm{n}=10$ ). All participants pertained to the category $\mathrm{A}$, which composes the upper rope graduation in the competition (purple, purple-brown, brown, and brown-red). Two evaluation batteries were set up: 1) anthropometry and somatotype determination; and 2) execution of physical performance tests. The two evaluation batteries were executed during the preliminary phase of the competition, which corresponded to the three-first days of the world championship. In this way, it was possible to ensure that the participants were not fatigued from the competition and were ready to go through the evaluation batteries. The present study was conducted in accordance with the requirements stipulated in the Declaration of Helsinki and all study procedures were approved by the Research and Ethics Committee of the Federal University of Vale do Sao Francisco (protocol 2.210.868 CEDEP).

Anthropometric evaluation. The anthropometric evaluation followed the guidelines of the International Society for the Advancement of Kinanthropometry (Marfell-Jones et al., 2012). BW was measured by a digital scale (EKS 9824) with a variation of $0.1 \mathrm{~kg}$. Height and the circumferences of waist, hip, thigh, leg, relaxed arm, and flexed arm were measured by a flexible steel tape with sequential scale, resolution in millimeters, with 2 meters long and $6 \mathrm{~mm}$ wide (Cescorf, Porto Alegre/RS, Brazil). Body mass index was then calculated by weight $(\mathrm{kg}) /$ height-squared $\left(\mathrm{m}^{2}\right)$ and the waist-to-hip ratio through the waist-hip equation. The skinfolds of the triceps brachii, subscapular, supraspinal, abdominal, medial thigh, chest, and calf regions were evaluated in triplicate using a skinfold caliper with sensitivity of $0.1 \mathrm{~mm}$, total amplitude of 85 $\mathrm{mm}$, and pressure of $10 \mathrm{~g}^{\bullet} \mathrm{mm}^{-2}$ (Cescorf/Mitutoyo, Porto Alegre/RS, Brazil). The biepicondylar humerus and femur breadths were measured once by a stainless-steel bone caliper, with $16 \mathrm{~cm}$ in length, and resolution in millimeters (Cescorf, Porto Alegre/RS, Brazil). Body density was 
obtained from the Jackson and Pollock's predictive equation (Jackson \& Pollock, 1978) and body fat percentage (BF) was computed from Siri Equation (Siri, 1993), which was posteriorly corrected for the Cescorf skinfold caliper (Okano et al., 2008). Lastly, somatotype was determined and represented in the somatochart following the guidelines of Heath and Carter (Carter).

Functional performance evaluation. Immediately after the anthropometric measurements, several motor tests were set up to measure key physical abilities of capoeira athletes. The functional tests were conducted in the following order: one-minute push-up test (push-up), one-minute sit-up test (sit-up), sit-and-reach test, squat vertical jump performance test (SJ), countermovement vertical jump performance test (CMJ), and quadrant jump test (QJT). The participants performed one repetition to familiarize with each test before its initiation and their performance were not hidden from other participants. The participants were instructed to execute their best performance, without been verbally encouraged, and they were barefoot in the execution in each of the tests beforementioned as an attempt to mimic the competition conditions. The push-up and sit-up were performed once, whereas the sit-and-reach test, SJ, CMJ, and QJT were performed three times with a 30-second interval between each trial. The maximum value was considered for the evaluation.

The push-up evaluated the muscular endurance of the upper limbs' muscles. The participants were placed in the ventral decubitus positions, with their hands aligned with the pectoral region and 1-2 centimeters away from the shoulders. The initial position consisted with the elbows extended and the repetition was considered when the participant approached the chest to the ground and returned to the initial position. The participants were instructed to inhale in the eccentric phase and to exhale in the concentric phase of the movement. The objective was to perform the maximum number of repetitions in one minute (Pollock \& Wilmore, 2009).

The sit-up test evaluated the muscular endurance of the abdomen muscles. The participants positioned themselves in the dorsal decubitus position. Their feet were supported and fixed on the ground by the investigator. The knee and hip articulations were $90^{\circ}$ flexed with the arms crossed and hands resting on the shoulders. The participants were instructed to perform a trunk flexion until the elbows touched the anterior portion of the thighs. The participants were instructed to inhale in the eccentric phase and to exhale in the concentric phase of the movement. The objective was to perform the maximum number of repetitions in one minute (Pollock \& Wilmore).
The sit-and-reach test evaluated the range of motion of the joints of the posterior muscle chain (triceps sural, hamstrings, gluteal, and spinalerectors). The sit-and-reach box proposed by Welss (Sanny®, Curitiba/PR, Brazil) was used for this test. The dimensions of the box were $30.5 \mathrm{~cm}$ x $30.5 \mathrm{~cm} \times 30.5 \mathrm{~cm}$ with $26.0 \mathrm{~cm}$ long scale in its extension. The zero point was at the closest extremity to the subject and the $26 \mathrm{~cm}$ coincided with the place that the feet were supported. The participants were instructed to sit on the ground and position their feet on the indicated place of the box with knees extended. During the execution hands were overlapped and elbows extended, and knees were kept extended by the investigator. The objective was to flex the trunk while exhaling in order to advance the hands as much as possible in the measurement scale (Ribeiro et al., 2010).

Two vertical jump tests were performed to measure the participants' explosive and elastic forces of the lower limbs' muscles, and a specific jump plate (Cefise®, São Paulo/SP, Brazil) with an interface to a microcomputer and the Jump System Pro v. 1.0 software were used to measure jump height $(\mathrm{cm})$ and relative power (watts $/ \mathrm{kg}$ ). The SJ were conducted first to evaluate the explosive force of the lower limbs' muscles. For this test, the participants held a semi-squat position while maintaining their hands position at their waist region for three seconds before executing the vertical jump. After the three trials of the SJ, the participants were instructed to execute the $\mathrm{CMJ}$ to measure the elastic force of the lower limbs' muscles. For this test, the participants performed the jump starting from the standing position going to a semi-squat using the stretch-shortening cycle. Lastly, the elasticity index (EI) was computed by the following equation proposed by Lara et al. (2006): EI $=(C M J-S J) \div S J \times 100$.

The QJT was used to evaluate agility, in which the participants had to displace themselves on a cross marked adhesive tape on the ground, with one meter of length by one meter of width. The participants jumped through the quadrants as quickly as possible for 10 seconds with their feet together. Each displacement from one quadrant to another without touching the adhesive tape was considered as a correct jump and the maximum value was considered for evaluation (Johnson \& Nelson, 1969).

Statistical Analysis. Data are expressed as mean, standard deviation, coefficient of variation, minimum and maximum values. The Shapiro-Wilk test was used to test normality and the Mauchly's test was applied to verify the sphericity of the data. The Greenhouse-Geisser correction was adopted if sphericity was violated. To compare the anthropometric and functional values from the study subgroups the oneway ANOVA was used and the Tukey Post Hoc was applied 
to identify the pairs of differences. The F-ratio and degrees of freedom were reported. Partial eta squared $\left(\eta p^{2}\right)$ was calculated to determine the effect size with a value of 0.2 ; 0.5; 0.8 indicating a small, medium, and large effect size, respectively. Pearson's linear correlation coefficient was calculated to quantify the degree of association between anthropometric and functional performance variables. The alpha level was set at $5 \%$ and all the statistical analysis was conducted in the SPSS software (version 22.0 for windows. IBM Corp., Armonk, NY).

\section{RESULTS}

Table I shows the general characteristics and anthropometry of the elite capoeira athletes. Statistical differences were found among the three categories with a moderate effect size for BW $\left(\mathrm{F}_{[2.47]}=57.577 ; \mathrm{p}<0.001\right.$; $\left.\eta \mathrm{p}^{2}=0.71\right)$ and BMI $\left(\mathrm{F}_{[2.47]}=17.650 ; \mathrm{p}<0.001, \eta \mathrm{p}^{2}=\right.$ $0.43)$. For the height, the VIOLA subgroup presented lower values compared to the MEDIO and GUNGA subgroups $\left.\left(\mathrm{F}_{[2.47]}\right]=10.435 ; \mathrm{p}<0.001 ; \eta \mathrm{p}^{2}=0.31\right)$.
There was a significant difference with a small effect size between the VIOLA and GUNGA subgroups for the QJT $\left(\mathrm{F}_{[2.47]}=4.299 ; \mathrm{p}=0.019 ; \eta \mathrm{p}^{2}=0.16\right)$. Table II.

Table III shows the values corresponding to the somatotype and the mean values were (2.8-6.0-1.3 / 3.36.5-1.0/3.5-7.8-0.6) for the VIOLA, MEDIO, and GUNGA subgroups, respectively. The "endo-mesomorph" classification was found in the three subgroups in spite of differences that occurred in the MESO when comparing the subgroups VIOLA and MEDIO with GUNGA $\left(\mathrm{F}_{[2.47]}=7.617\right.$; $\left.\mathrm{p}=0.001 ; \eta \mathrm{p}^{2}=0.25\right)$ and in the ectomorphic component (ECTO) when comparing the subgroup VIOLA with $\operatorname{GUNGA}\left(\mathrm{F}_{[2.47]}=3.899 ; \mathrm{p}=0.027 ; \eta \mathrm{p}^{2}=0.14\right)$.

Figure 2 shows the correlation between somatotype and functional performance of elite capoeira athletes. There was a negative correlation between the endomorphic component (ENDO) and the performance in the sit-up ( $<<$ 0.001), push-up ( $\mathrm{p}=0.004)$, SJ ( $\mathrm{p}=0.001)$, and CMJ ( $<<$ 0.001 ). In addition, the performance in the push-up test positively correlated with the MESO $(p=0.009)$ and negatively with the ECTO $(p=0.005)$.

Table I. General characteristics and anthropometry of elite capoeira athletes in the three categories $(n=50)$.

\begin{tabular}{|c|c|c|c|c|c|c|c|c|c|}
\hline & \multicolumn{3}{|c|}{ VIOLA $(n=15)$} & \multicolumn{3}{|c|}{ MEDIO $(n=25)$} & \multicolumn{3}{|c|}{ GUNGA $(n=10)$} \\
\hline & $\mathrm{X} \pm \mathrm{SD}$ & Range & $\begin{array}{l}\text { CV } \\
(\%)\end{array}$ & $\mathrm{X} \pm \mathrm{SD}$ & Range & $\begin{array}{l}\text { CV } \\
(\%)\end{array}$ & $\mathrm{X} \pm \mathrm{SD}$ & Range & $\begin{array}{l}\text { CV } \\
(\%)\end{array}$ \\
\hline $\begin{array}{c}\text { Age } \\
\text { (years) }\end{array}$ & $32.8 \pm 7.2$ & $(19.0-44.0)$ & 30 & $34.3 \pm 5.3$ & $(24.0-49.0)$ & 16 & $36.1 \pm 4.8$ & $(30.0-46.0)$ & 13 \\
\hline $\begin{array}{c}\text { PT } \\
\text { (years) }\end{array}$ & $20.7 \pm 6.2$ & $(11.0-35.0)$ & 9 & $21.3 \pm 4.6$ & $(15.0-35.0)$ & 22 & $24.3 \pm 6.3$ & $(18.0-33.0)$ & 21 \\
\hline $\begin{array}{l}\text { BW } \\
(\mathbf{k g})\end{array}$ & $71.1 \pm 6.3^{*}$ & $(57.3-76.9)$ & 4 & $81.8 \pm 2.9 \dagger$ & $(77.0-85.9)$ & 5 & $93.6 \pm 6.0$ & $(86.0-106.9)$ & 7 \\
\hline $\begin{array}{c}\text { Height } \\
\text { (cm) }\end{array}$ & $168.0 \pm 7.1 *$ & $(155.0-184.0)$ & 8 & $174.0 \pm 4.5$ & $(167.0-182.0)$ & 3 & $178.0 \pm 4.4$ & $(170.0-184.0)$ & 2 \\
\hline $\begin{array}{c}\text { BMI } \\
\left(\mathrm{kg} / \mathrm{m}^{2}\right)\end{array}$ & $25.0 \pm 1.9 *$ & $(21.6-28.5)$ & 8 & $27.0 \pm 1.5 \dagger$ & $(24.0-29.0)$ & 6 & $29.4 \pm 1.9$ & $(26.0-33.3)$ & 7 \\
\hline WHR & $0.88 \pm 0.03$ & $(0.83-0.94)$ & 4 & $0.86 \pm 0.03$ & $(0.81-0.95)$ & 3 & $0.86 \pm 0.02$ & $(0.83-0.90)$ & 3 \\
\hline $\begin{array}{l}\text { BF } \\
(\%)\end{array}$ & $9.8 \pm 3.4$ & $(4.9-15.6)$ & 35 & $11.9 \pm 3.6$ & $(6.7-20.0)$ & 30 & $12.5 \pm 5.9$ & $(5.8-20.8)$ & 47 \\
\hline
\end{tabular}

Note: $\mathrm{X}=$ mean; $\mathrm{SD}=$ standard deviation; $\mathrm{CV}=$ coefficient of variation; $\mathrm{PT}=$ practice time; $\mathrm{BW}=$ body weight; $\mathrm{BMI}=$ body mass index; WHR = waist-to-hip ratio; $\mathrm{BF}=$ body fat. $* \mathrm{p}<0.05$ to MEDIO and GUNGA. $\dagger \mathrm{p}<0.05$ to GUNGA.

\section{DISCUSSION}

According to our knowledge, the current study is the first to investigate anthropometric characteristics associated with functional performance of male capoeira competitors at international level. The main findings show that elite capoeira athletes present a predominance of the MESO, regardless the weight categories. Furthermore, the functional performance was similar between the VIOLA, MEDIO, and GUNGA subgroups, and all athletes were classified as excellent for the push-up, sit-up, and sit-and-reach tests (Pollock \& Wilmore). 
ALMEIDA, L. G.; NUMATA FILHO, E. S.; DOS SANTOS, G. A.; CARDOSO, J. T. C. \& MOREIRA, S. R. Anthropometric profile and functional performance of capoeira competitors in the world games. Int. J. Morphol., 39(4):969-976, 2021

Table II. Functional performance of elite capoeira athletes in the three categories $(n=50)$.

\begin{tabular}{|c|c|c|c|c|c|c|c|c|c|}
\hline & \multicolumn{3}{|c|}{ VIOLA $(n=15)$} & \multicolumn{3}{|c|}{$\operatorname{MEDIO}(n=25)$} & \multicolumn{3}{|c|}{ GUNGA $(n=10)$} \\
\hline & $\mathrm{X} \pm \mathrm{SD}$ & Range & $\begin{array}{l}\text { CV } \\
(\%)\end{array}$ & $\mathrm{X} \pm \mathrm{SD}$ & Range & $\begin{array}{l}\text { CV } \\
(\%)\end{array}$ & $\mathrm{X} \pm \mathrm{SD}$ & Range & $\begin{array}{l}\text { CV } \\
(\%)\end{array}$ \\
\hline $\begin{array}{l}\text { Push-up } \\
\text { (reps) }\end{array}$ & $37.0 \pm 11.2$ & $(20.0-64.0)$ & 30 & $39.6 \pm 9.1$ & $(22.0-57.0)$ & 23 & $38.9 \pm 12.4$ & $(23.0-59.0)$ & 32 \\
\hline $\begin{array}{c}\text { Sit-up } \\
\text { (reps) }\end{array}$ & $41.2 \pm 6.6$ & $(25.0-52.0)$ & 16 & $41.6 \pm 8.8$ & $(21.0-53.0)$ & 21 & $34.6 \pm 8.7$ & $(22.0-50.0)$ & 25 \\
\hline $\begin{array}{l}\text { Sit-and-reach } \\
\text { (cm) }\end{array}$ & $39.8 \pm 4.8$ & $(33.5-49.0)$ & 12 & $40.4 \pm 5.0$ & $(32.0-50.0)$ & 12 & $38.5 \pm 6.3$ & $(28.0-48.5)$ & 17 \\
\hline $\begin{array}{l}\text { QJT } \\
\text { (pts) }\end{array}$ & $32.3 \pm 4.5^{*}$ & $(23.0-41.0)$ & 14 & $30.5 \pm 3.4$ & $(24.0-38.5)$ & 11 & $27.6 \pm 3.8$ & $(20.5-33.5)$ & 14 \\
\hline $\begin{array}{l}\text { SJ } \\
(\mathbf{c m})\end{array}$ & $35.1 \pm 6.2$ & $(25.5-47.4)$ & 18 & $33.1 \pm 5.7$ & $(24.5-48.8)$ & 17 & $32.6 \pm 8.8$ & $(22.6-47.1)$ & 27 \\
\hline $\begin{array}{l}\text { CMJ } \\
(\mathbf{c m})\end{array}$ & $37.8 \pm 5.7$ & $(30.0-49.3)$ & 15 & $36.3 \pm 5.4$ & $(28.0-50.4)$ & 15 & $35.9 \pm 10.2$ & $(23.0-51.6)$ & 29 \\
\hline $\begin{array}{c}\text { SJ } \\
(\text { Watts/kg) }\end{array}$ & $25.5 \pm 2.2$ & $(22.9-29.9)$ & 9 & $25.4 \pm 2.1$ & $(21.5-30.3)$ & 9 & $24.3 \pm 2.8$ & $(20.6 \pm 29.8)$ & 12 \\
\hline $\begin{array}{c}\text { CMJ } \\
\text { (Watts/kg) }\end{array}$ & $26.5 \pm 2.2$ & $(23.8-30.5)$ & 8 & $26.5 \pm 1.8$ & $(23.0 \pm 30.8)$ & 7 & $25.4 \pm 3.1$ & $(21.8-31.2)$ & 12 \\
\hline $\begin{array}{l}\text { EI } \\
(\%)\end{array}$ & $8.4 \pm 8.5$ & $(-2.6-30.2)$ & 101 & $10.4 \pm 6.3$ & $(-3.1-23.7)$ & 60 & $10.0 \pm 9.9$ & $(-1.5-30.6)$ & 99 \\
\hline
\end{tabular}

Note: $\mathrm{X}=$ mean; $\mathrm{SD}=$ standard deviation; $\mathrm{CV}=$ coefficient of variation; $\mathrm{QJT}=$ quadrant jump test; $\mathrm{SJ}=$ squat vertical jump; $\mathrm{CMJ}=$ countermovement jump; EI = elasticity index. * p <0.05 to GUNGA.

Table III. Somatotype and its classification of the elite capoeira athletes in the three categories $(n=50)$.

\begin{tabular}{|c|c|c|c|c|c|c|c|c|c|}
\hline & \multicolumn{3}{|c|}{ VIOLA $(n=15)$} & \multicolumn{3}{|c|}{ MEDIO $(n=25)$} & \multicolumn{3}{|c|}{ GUNGA $(n=10)$} \\
\hline & $\mathrm{X} \pm \mathrm{SD}$ & Range & $\begin{array}{l}\mathrm{CV} \\
(\%)\end{array}$ & $\mathrm{X} \pm \mathrm{SD}$ & Range & $\begin{array}{l}\text { CV } \\
(\%)\end{array}$ & $\mathrm{X} \pm \mathrm{SD}$ & Range & $\begin{array}{l}\mathrm{CV} \\
(\%)\end{array}$ \\
\hline Endomorphy & $2.8 \pm 0.7$ & $(1.5-4.0)$ & 26 & $3.3 \pm 1.0$ & $(1.8-6.4)$ & 31 & $3.5 \pm 1.5$ & $(1.4-6.0)$ & 44 \\
\hline Mesomorphy & $6.0 \pm 1.2 *$ & $(3.9-7.9)$ & 21 & $6.5 \pm 1.2 *$ & $(4.6-9.0)$ & 19 & $7.8 \pm 0.6$ & $(7.0-9.0)$ & 8 \\
\hline Ectomorphy & $1.3 \pm 0.8^{*}$ & $(0.2-3.2)$ & 60 & $1.0 \pm 0.6$ & $(0.2-2.3)$ & 64 & $0.6 \pm 0.4$ & $(0.1-1.7)$ & 71 \\
\hline Classification & \multicolumn{3}{|c|}{ Endo-mes omorph } & \multicolumn{3}{|c|}{ Endo-mesomorph } & \multicolumn{3}{|c|}{ Endo-mesomorph } \\
\hline
\end{tabular}

Note: $\mathrm{X}=$ mean; $\mathrm{SD}=$ standard deviation; $\mathrm{CV}=$ coefficient of variation. $* \mathrm{p}<0.05$ to GUNGA.

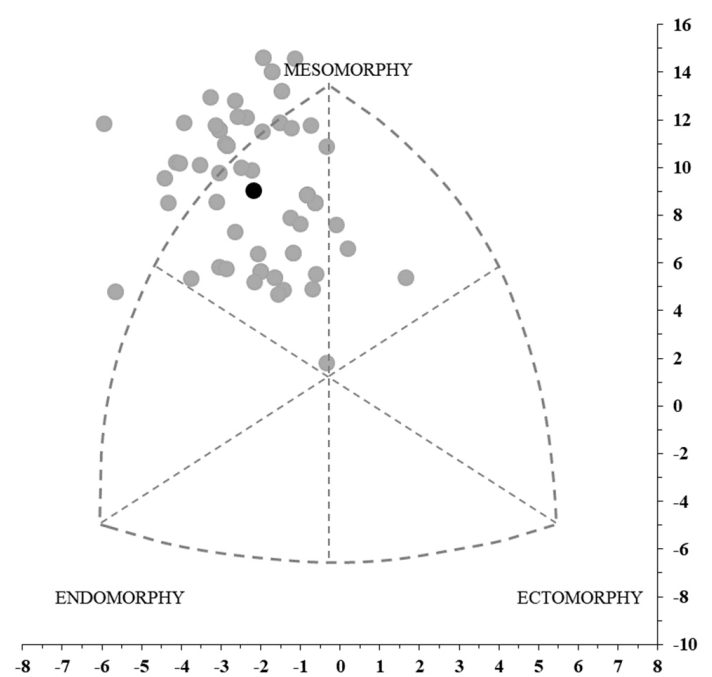

Capoeira athletes presented the predominance of the MESO, and they had similar BF and endormophy despite divergences in BW and BMI across the three categories. In line, a study conducted by Noh et al. compared the somatotype of elite boxing athletes, and all boxers pertaining to the light middleweight, middleweight, and the heavyweight category showed the predominance of the MESO. In addition, all categories had similar values for the ENDO and the heavyweight category had a higher value for the MESO. This evidence together suggests that the higher weight observed in the heaviest category was accounted by increased muscle mass rather than body fat.

Fig. 1. Predominance of the MESO among other somatotype components for the sample analyzed. The black circle representing the somatotype mean of all sample. 

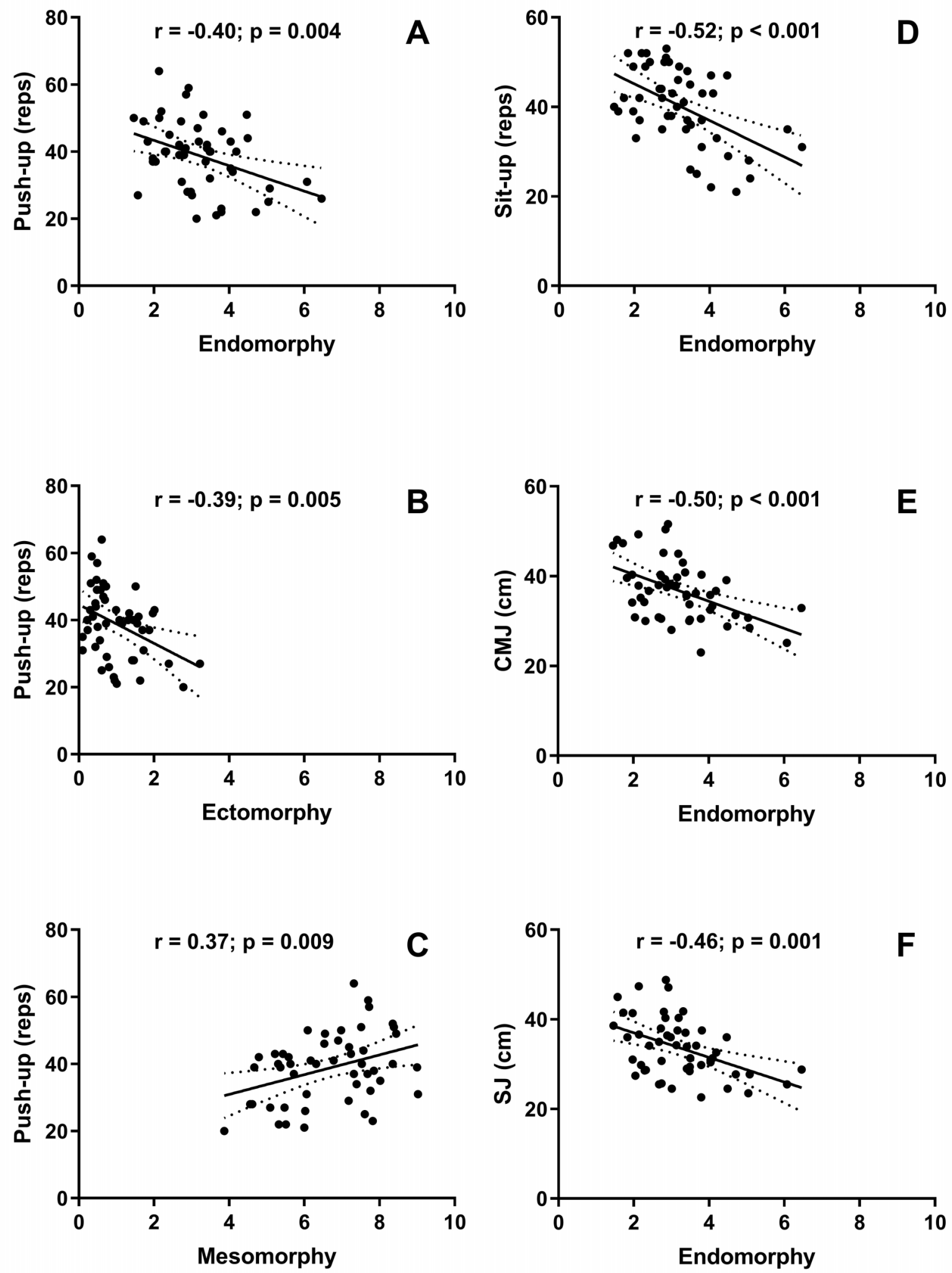

Fig. 2. Correlation between somatotype and functional performance of elite capoeira athletes. 
Nevertheless, Franchini et al. showed that elite judo athletes pertaining to heavier weight categories had greater not only the MESO, but also the ENDO compared to lighter categories. The divergence across studies may be caused by different functional performance requirements within each modality, which requires further investigation.

Greco-Roman (Neogi et al.), karate (Sánchez-Puccini et al.), judo (Franchini et al.), boxing (Noh et al.), taekwondo (Bridge et al.), and mixed martial arts athletes (Marinho et al., 2016) have the predominance of the MESO. Importantly, top level athletes present higher MESO while being compared to ordinary practitioners in a combat sport modality. For instance, Noh et al. compared the somatotype of elite male boxing athletes pertaining to different weight categories to boxing practitioners, and showed that the latter category had lower MESO and higher ENDO. In addition, a review article suggested that international taekwondo athletes were predominantly classified as MESO and had lower values for the ENDO compared to athletes from national and recreational level (Bridge et al.). The present study did not compare top-level capoeira athletes with their counterparts at national and recreational levels, however, there was an inverse association between the ENDO with the performance in the push-up, sit-up, CMJ, and SJ, and the MESO was positively associated with the push-up. Therefore, it is reasonable to hypothesize that capoeira athletes competing at international level are likely to have higher MESO and lower ENDO compared to their counterparts at lower levels of competition, however, this requires further confirmation.

The present study suggests that the accumulation of fat in the central and peripheral regions impairs performance in tasks that require abdominal, upper, and lower body muscle strength, which presumably hinder performance in capoeira. In addition, Ackland et al. (2009) pointed out that muscularity is positively associated with several functional abilities, such as strength, endurance, speed, agility, and power, which are paramount attributes in a variety of sports, including capoeira. This evidence suggests that body fat reduction added to the maintenance and gain of muscularity are crucial for the achievement of high performance in the capoeira modality. Therefore, the anthropometric profile and functional performance demonstrated have practical applications for coaches in the formulation of appropriate training programs aiming the development of an ideal physical composition, which will be associated with highlevel performance in capoeira.

In the present study, the anthropometric and functional evaluations batteries started at 8 am and finished at $6 \mathrm{pm}$ during the preliminary phase of the competition and the assessments were conducted depending on the athlete's availability. Thus, the athletes were tested at different times of the day. In addition, the water and food intake before the evaluation tests were not assessed. Therefore, the results from the functional tests may be influenced by the energy intake previous to the tests and by the circadian rhythm, and the latter is known to have an influence on alertness and physical performance (Harrison et al., 2007). Furthermore, future studies should also compare the somatotype and functional profiles of international capoeira competitors with their counterparts at the lower levels of competitions for a better understanding on how the MESO, ENDO, and ECTO differ between these athletes.

\section{CONCLUSION}

Elite male competitors at international level of the ABADÁ-Capoeira School show predominance of the MESO in the somatotype regardless the weight category. Moreover, all capoeira athletes were classified as excellent for the sitand-reach, sit-up, and push-up, and the latter were positively corelated with the MESO. However, the ENDO was inversely associated with the sit-up, push-up, SJ, and CMJ.

\section{ACKNOWLEDGEMENT}

This work was supported by the foundation that supports science and technology in the province of Pernambuco (FACEPE) process IBPG-1203-4.09/16. The authors thank the FACEPE, and Marcos Paulo Alves dos Santos (Prof. Gibor), Devanildo de Amorim Souza, Daniel Moraes (Inst. Fhel), and Patricia Bastos Indaê (Inst ${ }^{\mathrm{a}}$. Indaê) for their support provided in the data collection.

ALMEIDA, L. G.; NUMATA FILHO, E. S.; DOS SANTOS, G. A.; CARDOSO, J. T. C. \& MOREIRA, S. R. Perfil antropométrico y desempeño funcional de los competidores de capoeira en los juegos mundiales. Int. J. Morphol., 39(4):969-976, 2021.

RESUMEN: Este estudio tuvo como objetivo caracterizar el perfil antropométrico y el desempeño funcional de los competidores de élite en diferentes categorías en el campeonato mundial de la Escuela de Capoeira ABADÁ. Cincuenta deportistas masculinos de alto nivel se dividieron según sus categorías de peso: categoría ligera (VIOLA: $\leq 76,9 \mathrm{~kg} ; \mathrm{n}=15$ ); categoría intermedia (MEDIO: > $77,0 \mathrm{~kg}$ hasta $\leq 85,9 \mathrm{~kg} ; \mathrm{n}=25)$ y categoría pesada (GUNGA: $\geq$ $86,0 \mathrm{~kg} ; \mathrm{n}=10$ ). Se realizaron dos baterías de evaluación: 1) antropometría y determinación del somatotipo; 2) rendimiento físico en pruebas de flexiones, abdominales, sentadillas y estiramientos, prueba de salto en cuadrante, salto en cuclillas y 
salto con contramovimiento. La clasificación "endo-mesomorfo" predominó en las tres categorías. Hubo una diferencia en la prueba de salto de cuadrante entre los subgrupos VIOLA y GUNGA (F $\left.{ }_{[2,47]}=4,299 ; \mathrm{p}=0,019\right)$. El endomorfismo tuvo una correlación negativa $(\mathrm{p}<0.01)$ con el desempeño en los abdominales $(r=-$ $0,51)$, lagartijas $(r=-0,39), \mathrm{SJ}(\mathrm{r}=-0,45)$ y $\mathrm{CMJ}(\mathrm{r}=-0,49)$. Los competidores de élite masculinos a nivel internacional, independientemente de la categoría de peso, tienen predominio del componente mesomórfico del somatotipo. Además, todos los atletas de capoeira fueron clasificados como excelentes para sit-and-reach, sit-up y push-up, y estos últimos se correlacionaron positivamente con el MESO. Sin embargo, el ENDO se asoció inversamente con los abdominales, lagartijas, SJ y CMJ. De esta manera, el presente estudio ayuda a los entrenadores en la formulación de programas de entrenamiento adecuados que apunten al desarrollo de una composición física ideal, que estará asociada con un rendimiento de alto nivel en la capoeira.

PALABRAS CLAVE: Composición corporal; Rendimiento funcional físico; Desempeño atlético; Artes marciales.

\section{REFERENCES}

Ackland, T. R.; Elliott, B. C. \& Bloomfield, J. Applied anatomy and biomechanics in sport. 2nd ed. Champaign, Human Kinetics, 2009.

Andreato, L. V.; Franchini, E.; de Moraes, S. M. F.; Esteves, J. V. D. C.; Pastório, J. J.; Andreato, T. V.; Gomes, T. L. M. \& Vieira, J. L. L. Morphological profile of Brazilian Jiu-Jitsu elite athletes. Rev. Bras. Med. Esporte, 18(1):46-50, 2012.

Araújo, P. C. Abordagens Sócio-Antropológicas da Luta/Jogo da Capoeira: De uma Actividade Guerreira para uma Actividade Lúdica. Maia, Maia Instituto Superior-Série Estudos Monografia, 1997.

Bridge, C. A.; da Silva Santos, J. F.; Chaabène, H.; Pieter, W. \& Franchini, E. Physical and physiological profiles of taekwondo athletes. Sports Med., 44(6):713-33, 2014.

Carter, J. E. L. The Heath-Carter Anthropometric Somatotype. Instruction Manual. San Diego, Department of Exercise and Nutritional Sciences, San Diego State University, 2002. Available from: https://www.mdthinducollege.org/ebooks/statistics/HeathCarterManual.pdf

Franchini, E.; Sterkowicz-Przybycien, K. \& Takito, M. Y. Anthropometrical profile of judo athletes: comparative analysis between weight categories. Int. J. Morphol., 32(1):36-42, 2014.

Harrison, Y.; Jones, K. \& Waterhouse, J. The influence of time awake and circadian rhythm upon performance on a frontal lobe task. Neuropsychologia, 45(8):1966-72, 2007.

Jackson, A. S. \& Pollock, M. L. Generalized equations for predicting body density of men. Br. J. Nutr., 4O(3):497-504, 1978.

Johnson, B. L. \& Nelson, J. K. Practical Measurements for Evaluation in Physical Education. 2nd ed. Minneapolis, Burgess Publishing Company, 1969.

Lara, A.; Alegre, L. M.; Abián, J.; Jiménez, L.; Ureña, A. \& Aguado, X. The selection of a method for estimating power output from jump performance. J. Hum. Mov. Stud., 50:399-410, 2006.

Marfell-Jones, M. J.; Stewart, A. \& de Ridder, J. International Standards for Anthropometric Assessment. Wellington, International Society for the Advancement of Kinanthropometry, 2012.

Marinho, B. F.; Del Vecchio, F. B. \& Franchini, E. Condición física y perfil antropométrico de atletas de artes marciales mixtas. Rev. Artes Marciales Asiat., 6(2):7-18, 2011.
Marinho, B. F.; Follmer, B.; Del Conti Esteves, J. V. \& Andreato, L. V. Body composition, somatotype, and physical fitness of mixed martial arts athletes. Sport Sci. Health, 12:157-65, 2016.

Moreira, S. R. Movimentação básica na capoeira: uma análise da nomenclatura entre diferentes grupos. Pensar Prat., 20:4, 2017.

Moreira, S. R.; Carvalho, F. O.; de Moraes, J. F. V. N.; da Silva Carvalho, R. G.; de Araújo, R. C.; Teixeira-Araújo, A. A. \& Okano, A. H. Eight weeks of Capoeira progressive training program increases flexibility of beginners. Sport Sci. Health, 12:329-337, 2016.

Moreira, S. R.; Teixeira-Araujo, A. A.; Numata Filho, E. S.; Moraes, M. R. \& Simões, H. G. Psychophysiological characterization of different capoeira performances in experienced individuals: A randomized controlled trial. PloS One, 13:e0207276, 2018.

Neogi, A.; Tiwari, A.; Medabala, T.; Adhikari, S. \& Dey, S. K. Somatotype, body composition and anthropometric profiles of indian male greco-roman wrestlers. Int. J. Sport Stud. Health, 2(2):e93102, 2019.

Noh, J. W.; Kim, J. H.; Kim, M. Y.; Lee, J. U.; Lee, L. K.; Park, B. S.; Yang, S. M.; Jeon, H. J.; Lee, W. D.; Kwak, T. Y.; et al. Somatotype analysis of elite boxing athletes compared with nonathletes for sports physiotherapy. J. Phys. Ther. Sci., 26(8):1231-5, 2014.

Okano, A. H.; Carvalho, F. O.; Cyrino, E. S.; Gobbo, L. A.; Romanzini, M.; Glaner, M. F.; Reichert, F. F. \& Avelar A. Utilização do adipômetro CESCORF para estimativa da gordura corporal relativa a partir de equações validadas com o adipômetro Lange. J. Phys. Educ., 19(3):431-6, 2008

Pieter, W. \& Bercades, L. T. Somatotypes of national elite combative sport athletes. Braz. J. Biomotricity, 3:21-30, 2009.

Pollock, M. L.; Wilmore, J. H. Exercícios na Saúde e na Doença: Avaliação e Prescrição para Prevenção e Reabilitação. $2^{\mathrm{a}}$ ed. Rio de Janeiro, Guanabara Koogan, 2009.

Ribeiro, C. C. A.; Abad, C. C. C.; Barros, R. V. \& Neto, T. L. B. Level of flexibility through sit and reach test from research performed in São Paulo city. Rev. Bras. Cineantropom. Desempenho Hum., 12(6):41521, 2010 .

Sánchez-Puccini, M. B.; Argothy-Bucheli, R. E.; Meneses-Echávez, J. F.; López-Albán, C. A. \& Ramírez-Vélez, R. Anthropometric and physical fitness characterization of male elite karate athletes. Int. J. Morphol., 32(3):1026-31, 2014.

Santos, A. Capoeira Arte-Luta Brasileira. Cascavel, Assoeste, 2001.

Siri, W. E. Body composition from fluid spaces and density: analysis of methods. 1961. Nutrition (Burbank, Los Angeles County, Calif.)9(5):480-92, 1993.

Vieira, L. R. \& Assunção, M. R. Os desafios contemporâneos da capoeira. Rev. Textos Bras., 14:9-19, 2008.

Corresponding author:

Lucas Guimarães Almeida

Graduate Program in the Department of Physical Education

Federal University of Vale do São Francisco

Rua Ozelina Dias da Silva S/N Cond. Paulo VI

Quadra F, 0848904241

Juazeiro, Bahia BRAZIL

E-mail: lucasalmeida.juaz@gmail.com

Received: 03-03-2021

Accepted: 10-05-2021 